\title{
PERUBAHAN DALAM STRUKTUR KELUARGA
}

\author{
Puji Lestari dan Poerwanti Hadi Pratiwi \\ Jurusan Pendidikan Sosiologi, FIS, UNY \\ e-mail: ph_pratiwi@uny.ac.id
}

\begin{abstract}
Abstrak
Penelitian ini bertujuan untuk mengetahui perubahan yang terjadi dalam struktur keluarga, dengan fokus pada keluarga anak yang mengalami brokenhome dan anak yang bekerja sebagai tukang ojek payung di Malioboro, Yogyakarta. Metode penelitian yang digunakan dalam penelitian ini menggunakan metode kualitatif dengan paparan deskriptif analisis. Hasil penelitian menunjukkan bahwa anak sebagai aktor utama yang menjadi fokus pembahasan telah mengalami berbagai perubahan terkait status yang disandangnya di dalam keluarga. Anak yang bekerja sebagai tukang ojek payung misalnya, meskipun hanya bekerja pada musim hujan saja, namun uang yang diperolehnya digunakan untuk membantu memenuhi kebutuhan keluarga seharihari. Penghasilan yang diperoleh selain untuk memenuhi kebutuhan sekolah (membeli sepatu, buku, seragam) juga ada yang diserahkan kepada orang tuanya. Orang tua mereka senang mendapatkan uang dari anak-anak mereka yang belum genap berusia 15 tahun tersebut. Kemudian anak-anak yang berasal dari keluarga broken-home, bila dianalisis dengan menggunakan teori struktural fungsional, terlihat bahwa dalam keluarga yang mengalami broken-home, orang tua kurang maksimal dalam menjalankan fungsinya. Fungsi keluarga yang kurang terpenuhi adalah fungsi ekonomi dan kasih sayang
\end{abstract}

Kata Kunci: Perubahan, Struktur Keluarga, Pekerja Anak

Abstract
This research aims to know the changes that occur in the family structure, with a focus on the family's broken-home and children worker who rent umbrellas in Malioboro, Yogyakarta. Research methods used in this study using qualitative method with descriptive analysis of exposure. The results showed that the main actor who became the focus of discussion has undergone various changes related status which he carried on in the family. Children worker who rent umbrellas for instance, although the only works in the rainy season, but the money that he used to help meet the needs of the everyday family. Income earned in addition to meet the needs of schools (buy shoes, books, uniform) there are also submitted to his parents. Their parents love to get any money from their children who have not even 15 years old. Another example is the kids who come from family's broken-home, when analyzed using the structural functional theory, seen that in families experiencing broken-home parents, insufficient run function. The function of the family is less fulfilled is a function of economics and compassion.

Keywords: Change, Family Structure, Children Worker 


\section{Pendahuluan}

Dalam setiap masyarakat akan dijumpai institusi sosial bernama keluarga. Keluarga merupakan kelompok sosial yang kecil terdiri dari suami, isteri beserta anak-anaknya yang belum menikah. Keluarga tersebut lazimnya disebut rumahtangga, yang merupakan unit terkecil dalam masyarakat sebagai wadah pergaulan hidup. Suatu keluarga dianggap sebagai suatu sistem sosial, oleh karena memiliki unsur-unsur sistem sosial yang pada pokoknya mencakup kepercayaan, perasaan, tujuan, kaidah-kaidah, kedudukan dan peranan (Soekanto, 2004: 1). Secara tradisional hubungan darah lebih penting dari pada hubungan karena perkawinan, walaupun perkawinan merupakan salah satu upaya untuk mempertahankan hubungan darah tersebut.

Keluarga adalah suatu sistem interaksi yang mana tiap komponennya memiliki batasan yang selalu berubah dan derajat ketahanan untuk berubah yang bervariasi. Keluarga akan melalui suatu proses perubahan yang menghasilkan tekanan terhadap seluruh anggotanya karena setiap anggotanya tumbuh dan berkembang. Keluarga harus mempersiapkan diri untuk merespon perubahan kebutuhan anggotanya dari waktu ke waktu, bersiap untuk kejadian yang tidak direncanakan yang melibatkan anggotanya, dan bersiap menghadapi tekanan yang berasal dari luar sistem.

Secara nyata perubahan struktur keluarga ini bisa dilihat dalam institusi keluarga saat ini. Seiring dengan perkembangan zaman, status dan peran antara suami-istri pada beberapa keluarga sama/ sederajat dalam pemenuhan kebutuhan fungsi ekonomi. Artinya, suami dan istri dapat sama-sama bekerja karena memiliki kesempatan dan kemampuan yang sama. Alasan untuk bekerja pun bervariasi, mulai dari untuk tuntutan pemenuhan kebutuhan hidup sehari-hari, aktualisasi diri diranah publik, sampai dengan pengembangan karier. Perubahan fungsi ini pada akhirnya berakibat pada perubahan struktur keluarga.

Status dan peranan dalam perkawinan sedang berubah dengan cepat, di mana para suami dan para istri menduduki posisi-posisi sosial yang baru dan menjalankan bidangbidang baru baik dalam masyarakat luas maupun dalam keluarga. Bagi keluarga yang dapat dengan cepat 
menyesuaikan diri terhadap perubahan yang terjadi, maka tidak akan menemui masalah yang berarti. Namun bagi keluarga yang tidak siap menghadapi perubahan, maka akan mengalami disorganisasi. Khairuddin (2002: 120) mengemukakan bahwa dalam bentuk luas, disorganisasi keluarga meliputi berbagai kelemahan-kelemahan,

ketidaksesuaian (maladjustment), atau putusnya/ retaknya jalinan ikatan anggota-anggota dari kelompok bersama (broken-home). Disorganisasi keluarga dapat terjadi tidak hanya karena keteganganketegangan antara suami-istri, tetapi juga antara orang tua dan anak-anak, serta antara saudara kandung.

Keretakan antara suami-istri lebih serius daripada keretakan yang meliputi orang tua dan anak-anak. Istilah "broken home" biasanya digunakan untuk menggambarkan keluarga yang berantakan akibat orang tua tidak lagi peduli dengan situasi dan keadaan keluarga di rumah. Orang tua tidak lagi perhatian terhadap anak-anaknya, baik masalah di rumah, sekolah, sampai pada perkembangan pergaulan anakanaknya di masyarakat. Broken home dapat dilihat dari dua aspek yaitu: 1) keluarga itu terpecah karena strukturnya tidak utuh sebab salah satu dari kepala keluarga itu meninggal dunia atau telah bercerai, 2) orang tua tidak bercerai akan tetapi struktur keluarga itu tidak utuh lagi karena ayah atau ibu sering tidak di rumah, atau tidak memperlihatkan kasih sayang lagi. Misalnya orang tua sering bertengkar sehingga keluarga itu tidak sehat secara psikologis, Khairuddin (2002: 130). Keluarga ini mulai muncul dan menjadi sebuah gaya hidup dan struktur baru di negeri ini.

Perubahan dalam struktur keluarga lainnya dapat dilihat dari fenomena pekerja anak. Pada kalangan keluarga dengan ekonomi yang lemah, anak selain sebagai penerus keturunan juga mempunyai manfaat ekonomis bagi keluarga. Keberadaan anak dianggap sebagai faktor produksi yang membantu orang tua untuk melakukan kegiatan/aktivitas ekonomi sehingga kehadiran anak diharapkan dapat menanggulangi masalah ekonomi yang melilit keluarga. Pelibatan anak dalam pekerjaan merupakan strategi keluarga untuk menambah ekonomi keluarga. Fenomena pekerja anak banyak muncul ditengah-tengah masyarakat kota yaitu sekitar 2,1 juta pekerja anak termasuk di dalamnya anak jalanan. Pada usia yang seharusnya masih mendapatkan 
perlindungan dan pengelolaan, pekerja anak justru menghadapi kerasnya kehidupan perkotaan (Septiarti, 2002: 28).

Anak-anak yang bekerja ini salah satu contohnya dapat terlihat di kawasan Malioboro, yang merupakan salah satu tempat wisata belanja di kota Yogyakarta. Banyak terlihat pekerja anak yang menjadi pekerja ojek payung di kawasan ini. Anak yang bekerja sebagai ojek payung ini kebanyakan berusia 7-15 tahun. Pekerjaan ojek payung ini adalah pekerjaan musiman yang hanya dilakukan pada saat musim hujan saja sehingga diluar musim hujan (musim kemarau) para pekerja ojek payung mau tidak mau harus melakukan pekerjaan lain agar tetap dapat memenuhi kebutuhan hidupnya.

Struktur dan fungsi di dalam masyarakat kontemporer sudah banyak berubah. Keluarga dan unit rumah tangga telah mengalami banyak perubahan dan penyesuaian. Ada berbagai faktor penyebab yang melahirkan perubahan dalam struktur keluarga di masyarakat. Menarik kiranya untuk mengkaji lebih lanjut bagaimana perubahan yang terjadi dalam struktur keluarga. Selanjutnya, penelitian ini mengambil fokus pada keluarga broken-home dan pekerja anak yang saat ini marak terjadi di Yogyakarta, khususnya untuk mengetahui gambaran perubahan dalam struktur keluarga.

Penerapan teori strukturalfungsional pada keluarga oleh Parsons adalah sebagai reaksi dari pemikiran-pemikiran tentang melunturnya atau berkurangnya fungsi keluarga karena adanya modernisasi. Bahkan menurut Parsons, fungsi keluarga pada zaman modern, terutama dalam hal sosialisasi anak dan tension management untuk masing-masing anggota keluarga, justru akan semakin terasa penting (Puspitawati, 2009: 5). Pendekatan strukturalfungsional adalah pendekatan teori sosiologi yang diterapkan dalam institusi keluarga. Keluarga sebagai sebuah institusi dalam masyarakat mempunyai prinsip-prinsip serupa yang terdapat dalam kehidupan sosial masyarakat. Pendekatan ini mempunyai warna yang jelas, yaitu mengakui adanya segala keragaman dalam kehidupan sosial. Keragaman ini merupakan sumber utama dari adanya struktur masyarakat. Dan akhirnya keragaman dalam fungsi sesuai dengan posisi seseorang dalam struktur sebuah sistem (Megawangi, 2001). 


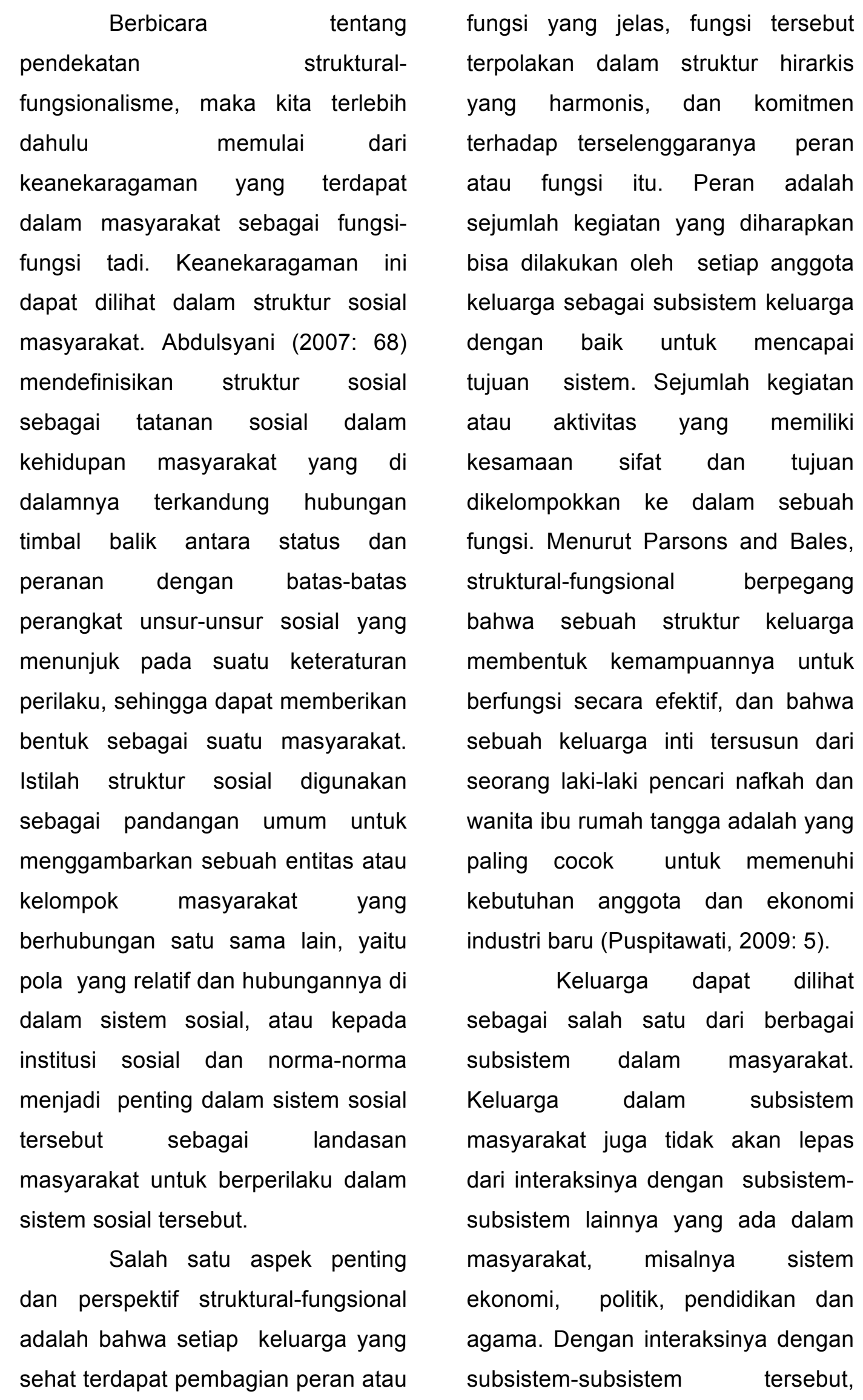


keluarga berfungsi untuk memelihara keseimbangan sosial dalam masyarakat (equilibrium state).

Penerapan teori struktural fungsional dalam konteks keluarga terlihat dari struktur dan aturan yang ditetapkan. Dinyatakan oleh Chapman (dalam Puspitawati, 2006) bahwa keluarga adalah unit universal yang memiliki peraturan, seperti peraturan untuk anak-anak agar dapat belajar untuk mandiri. Tanpa aturan atau fungsi yang dijalankan oleh unit keluarga, maka unit keluarga tersebut tidak memiliki arti (meaning) yang dapat menghasilkan suatu kebahagiaan. Struktur dalam keluarga dianggap dapat menjadikan institusi keluarga sebagai sistem kesatuan. Ada tiga elemen utama dalam struktur internal keluarga yang saling kait mengait yaitu;

a. Status sosial. Berdasarkan status sosial, keluarga nuklir biasanya distruktur oleh tiga struktur utama, yaitu: bapak/ suami, ibu/ isteri, dan anak-anak. Struktur ini dapat pula berupa figur-figur seperti: "pencari nafkah", ibu rumah tangga, anak balita, anak sekolah, remaja, dan lain-lain.

b. Fungsi sosial. Konsep peran sosial dalam teori ini menggambarkan peran dari masing-masing individu atau kelompok menurut status sosialnya dalam sebuah sistem sosial.

c. Norma sosial. Norma sosial adalah sebuah peraturan yang menggambarkan bagaimana sebaiknya seseorang bertingkah laku dalam kehidupan sosialnya. Seperti halnya fungsi sosial, norma sosial adalah standar tingkah laku yang diharapkan oleh setiap aktor.

Aspek fungsional sulit dipisahkan dengan aspek struktural karena keduanya saling berkaitan. Levy selanjutnya mengatakan bahwa tanpa ada pembagian tugas yang jelas pada masing-masing aktor dengan status sosialnya, maka fungsi keluarga akan terganggu yang selanjutnya akan mempengaruhi sistem yang lebih besar lagi (Puspitawati, 2009). Hal ini bisa terjadi kalau ada satu posisi yang perannya tidak dapat dipenuhi, atau konflik akan terjadi karena tidak adanya kesepakatan siapa yang akan memerankan tugas apa. Apabila ini terjadi, maka keberadaan institusi keluarga tidak akan berkesinambungan. Levy selanjutnya membuat daftar tentang persyaratan struktural yang harus dipenuhi agar struktur keluarga sebagai sistem dapat berfungsi: 
1. Diferensiasi peran. Dari serangkaian tugas dan aktivitas yang harus dilakukan dalam keluarga, maka harus ada alokasi peran untuk setiap aktor dalam keluarga. Terminologi diferensiasi peran bisa mengacu pada umur, gender, generasi, juga posisi status ekonomi dan politik dari masing-masing aktor.

2. Alokasi solidaritas. Distribusi relasi antaranggota keluarga menurut cinta, kekuatan, dan intensitas hubungan. Cinta atau kepuasan menggambarkan hubungan antaranggota. Misalnya, keterikatan emosional antara seorang ibu dan anaknya. Kekuatan mengacu pada keutamaan sebuah relasi relatif terhadap relasi lainnya. Hubungan antara bapak dan anak lelaki mungkin lebih utama daripada hubungan antara suami dan istri pada suatu budaya tertentu. Sedangkan intensitas adalah kedalaman relasi antaranggota menurut kadar cinta, kepedulian, ataupun ketakutan.

3. Alokasi ekonomi. Distribusi barang-barang dan jasa untuk mendapatkan hasil yang diinginkan. Diferensiasi tugas juga ada dalam hal ini terutama dalam hal produksi, distribusi dan konsumsi dari barang dan jasa dalam keluarga.

4. Alokasi politik. Distribusi kekuasaan dalam keluarga dan siapa yang bertanggung jawab atas setiap tindakan anggota keluarga. Agar keluarga dapat berfungsi maka distribusi kekuasaan pada tingkat tertentu diperlukan.

5. Alokasi integrasi dan ekspresi. Distribusi teknik atau cara untuk sosialisasi, internalisasi, dan pelestarian nilai-nilai dan perilaku yang memenuhi tuntutan norma yang beriaku untuk setiap anggota keluarga.

\section{Metode}

Metode penelitian yang digunakan dalam penelitian ini mengunakan metode kualitatif dengan paparan deskriptif analisis. Teknik pengumpulan data menggunakan observasi, wawancara, dan dokumentasi. Penentuan informan menggunakan purposive sampling dengan kriteria informan sebagai berikut: merupakan anggota keluarga brokenhome, (2) merupakan anak yang bekerja sebagai pekerja ojek payung, (3) mengetahui bagaimana kondisi keluarga. Dalam penelitian ini, 
informan penelitian adalah orang tua dan anak dari keluarga broken-home, pekerja ojek payung anak yang berusia antara 7-14 tahun, orang tua pekerja ojek payung anak dan masyarakat di sekitar lokasi penelitian.

\section{Hasil dan Pembahasan}

1. Perubahan yang Terjadi dalam

Struktur Keluarga Anak-anak yang Bekerja sebagai Tukang Ojek Payung

Kawasan Malioboro yang menjadi fokus penelitian ini adalah pada sepanjang jalan Malioboro yaitu mulai dari ujung utara malioboro (sebelum stasiun Tugu) sampai 0 $\mathrm{km}$, dimana pada sepanjang jalan Malioboro tersebut terdapat anakanak pekerja ojek payung yang menawarkan jasanya pada saat musim hujan. Penelitian ini juga meneliti kampung dimana anak-anak pekerja ojek payung tersebut tinggal. Kampung yang banyak terdapat anak-anak pekerja ojek payung yaitu salah satunya kampung Pajeksan dan Jogonegaran. Kampung ini terletak pada bagian belakang Malioboro yang berjejer juga dengan kampung yang lain. Akan tetapi dalam penelitian secara khusus lebih banyak membahas Kampung Pajeksan karena anak-anak pekerja ojek payung lebih banyak bertempat tinggal di kampung ini. Kampung Pajeksan terdiri dari 4 RW yakni RW 08, 09, 10, dan 11. Kampung Pajeksan berada di Kelurahan Sosromenduran dan Kecamatan Gedong Tengen. Kampung ini bisa dibilang padat dan kumuh karena banyak sekali berjejer rumah-rumah warga yang saling berdempetan. Tidak ada lahan bermain untuk anak, dan jalan untuk lewat juga terbilang sempit.

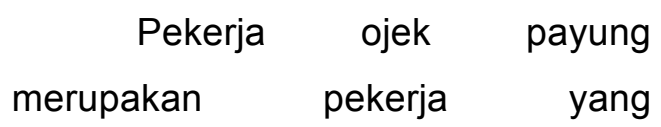
menawarkan jasa payung pada saat hujan turun. Mereka akan menawarkan kepada siapa saja yang membutuhkan payung, baik itu hanya sekedar untuk menyeberang jalan atau untuk berpindah tempat. Saat ini, pekerja ojek payung sudah banyak ditemukan, khususnya di kawasan Malioboro. Banyak dijumpai pekerja ojek payung yang kebanyakan adalah anak-anak kecil di daerah ini. Mereka tersebar dari ujung selatan Malioboro hingga ujung utara.

Anak-anak pekerja ojek payung hanya bekerja pada saat hujan saja dan mereka bekerja di luar waktu sekolah. Batas waktu mereka bekerja yaitu jam 8 malam, jadi apabila hujan terus menerus sampai 
melebihi jam 8 malam anak-anak tidak lagi bekerja. Jika tidak turun hujan, kegiatan sehari-hari mereka selain bersekolah yaitu bermain dengan teman-teman sebayanya, entah itu bermain sepak bola, bersepeda, bermain naga, berenang, ataupun yang lainnya. Jika sedang tidak musim hujan, otomatis anakanak tersebut tidak akan mendapatkan penghasilan tambahan karena mereka tidak bisa menjadi pekerja ojek payung. Terkecuali jika mereka mempunyai pekerjaan lain selain menjadi pekerja ojek payung.

Pada saat musim kemarau atau pada saat tidak hujan, anakanak pastinya membutuhkan uang untuk tetap memenuhi kebutuhannya. Untuk tetap memenuhi kebutuhannya, anak-anak pekerja ojek payung ini masih mengandalkan orang tuanya, dalam artian mereka masih meminta orang tuanya. Akan tetapi, orang tua hanya memberi uang kepada anaknya untuk ke sekolah, jika anak meminta uang untuk jajan atau untuk membeli keperluannya yang lain jarang dipenuhi. Jadi jika sedang tidak turun hujan dan anak-anak tidak mempunyai uang untuk jajan, mereka lebih memilih untuk bermain dengan teman-temannya dan mereka terpaksa menahan rasa ingin jajan karena orang tua mereka tidak memberikan uang jajan lebih.

$$
\text { Anak-anak pekerja ojek }
$$
payung ada juga yang memiliki pekerjaan atau kegiatan lain selain menjadi ojek payung, diantaranya Atn dan LI. Atn selain menjadi pekerja ojek payung juga ngedance di Malioboro, tepatnya di depan toko Liman. Ngedance ini dilakukan pada malam hari yaitu mulai sekitar jam 8 malam. Tetapi, tidak setiap malam Atn ikut ngedance karena dia juga masih berstatus menjadi siswa dan paginya harus ke sekolah. Hanya pada saat tertentu saja Atn ngedance misalnya jika ada jadwal libur sekolah. Selain hari libur sekolah, terkadang Atn juga ngedance tetapi jarang. Rata-rata penghasilan yang di peroleh Atn dari ngedance sekitar Rp. 30.000,00. Penghasilan tersebut tetap Atn berikan sebagian untuk orang tuanya.

Berbeda dengan LI, selain menjadi pekerja ojek payung LI juga ikut membuat kalung dan gelang di rumah tetangganya untuk di jual. Penghasilan yang di peroleh LI pun tidak pasti. Seperti yang ditutrkan oleh LI "yo nggak mesti, seikhlasnya mau ngasih berapa,dikasih 10, seribu". Terkadang LI mendapatkan upah sebesar Rp. 10.000,00 kadang juga hanya mendapatkan Rp. 
1.000,00. Walaupun upah LI sedikit tetapi LI tetap senang karena dia bisa mendapatkan uang untuk jajan. Selain membuat kalung dan gelang, pada saat hari libur sekolah LI juga bekerja menawarkan jasa hotel dan penginapan untuk pengunjung di Malioboro. Penghasilan yang diperolehpun cukup besar, seperti penuturannya: "aku waktu itu pernah dapet 50, dari hotelnya tu 30 ". Selain upah yang di berikan oleh pihak hotel atau penginapan, LI juga mendapatkan uang tips dari pengunjung.

$$
\text { Banyak faktor yang }
$$
melatarbelakangi mengapa anakanak mau bekerja, khususnya dalam hal ini anak-anak yang mau bekerja menjadi pekerja ojek payung. Berdasarkan hasil penelitian, faktorfaktor yang melatarbelakangi anakanak menjadi pekerja ojek payung diantaranya, yaitu: a. Faktor Lingkungan

Faktor lingkungan sangat berpengaruh terhadap tumbuh kembangnya anak. Apabila lingkungan tempat tinggal anak baik, maka anakpun akan tumbuh dengan baik, begitu pula sebaliknya. Lingkungan di mana anak pekerja ojek payung tinggal akan sangat mempengaruhi anak-anak lainnya untuk ikut bekerja. Berdasarkan informasi dari anak yang bekerja menjadi pekerja ojek payung, dapat diketahui bahwa awal mula mereka menjadi pekerja ojek payung adalah karena ajakan dari teman sebaya. Walaupun ada salah satu informan yang menjadi pekerja ojek payung bekerja karena alasan disuruh orang tua, tetapi selain disuruh orang tua juga karena adanya ajakan dari teman. Ajakan teman untuk mempengaruhi teman yang lain bekerja sangatlah besar, hampir setiap ajakan yang ditawarkan oleh teman dapat diterima oleh teman yang lain. Oleh sebab itu, anak-anak yang bekerja menjadi pekerja ojek payung dari waktu ke waktu jumlahnya terus bertambah.

Jumlah anak-anak yang bekerja menjadi ojek payung di kampung-kampung sekitar kawasan Malioboro sangatlah banyak, kebanyakan dari mereka adalah anak-anak dibawah umur. Masyarakat sekitar pun juga sudah menganggap lumrah dan biasa terhadap fenomena anak yang bekerja menjadi pekerja ojek payung. Masyarakat juga mengetahui dan sadar akan kondisi ekonomi yang terjadi pada keluarga anak pekerja ojek payung tersebut, sehingga masyarakat hanya bisa membiarkan begitu saja. 
Terus bertambahnya jumlah anak yang menjadi pekerja ojek payung dikarenakan karena lingkungan di mana mereka tinggal sangat mendukung sehingga bertambah banyaknya jumlah pekerja ojek payung tidak dapat dihentikan karena peran dari lingkungan sendiri juga sangat kurang. Masyarakat sekitar sudah sibuk dengan kesibukan masing-masing, sehingga mereka tidak mempunyai waktu untuk ikut membimbing dan mengarahkan anak-anak agar beralih pada kegiatan yang lebih bersifat positif daripada bekerja. Padahal jumlah anak yang ada di kampungkampung sekitar Malioboro khususnya di kampung Pajeksan sangat banyak, terutama anak-anak di bawah umur. Saat musim hujan tiba, jumlah mereka kurang lebih ada sekitar 30 anak, itu yang terlihat pada saat peneliti melakukan observasi, belum lagi anak-anak lain yang belum terlihat. Meskipun pekerjaan menjadi tukang ojek payung hanya dilakukan pada saat musim hujan saja, anak-anak tersebut terlihat lebih mementingkan mencari uang atau bekerja daripada kegiatan yang lain misalnya sekolah, bermain permainan anak-anak, dan lain sebagainya. Seperti yang dikemukakan salah seorang informan berikut ini:

"yang saya kuatirkan
begini, sekali duakali anak
jasa payung dapat uang
banyak sekolah pasti
keteteran apalagi pas
musimnya hujan perasaan
mereka lebih baik bolos. Itu
yang saya kuatirkan itu,
bahkan sudah pernah terjadi
pas hujan dia lagi sekolah
terus dia lari ke rumah wah
langsung ambil payung, jadi
kan takutnya nanti dia lebih
milih ngojek daripada sekolah
nah itu kan bahaya mbak"
(wawancara dengan bapak
Ags, tanggal 26 Maret 2014,
Pukul 13.00-14.00 WIB).

b. Faktor Keluarga

Selain faktor lingkungan, anak-anak menjadi pekerja ojek payung juga karena faktor keluarga. Keluarga, terutama orang tua ikut berperan dalam mendukung anakanaknya menjadi pekerja ojek payung. Seperti yang diungkapkan oleh Msd: "diajak temen sama disuruh", "sama ibuk". Msd merupakan 1 dari 9 informan yang bekerja disuruh oleh orang tuanya. Walaupun setelah melakukan wawancara dengan ibu dari Msd beliau tidak mengakui hal tersebut, tetapi masyarakat mengiyakan hal tersebut.

Dorongan dari orang tua Msd disini bersifat langsung yaitu dengan "menyuruh". Selain dorongan orang 
tua yang bersifat langsung, dorongan orang tua juga muncul secara tidak langsung. Berdasarkan wawancara dengan anak-anak pekerja ojek payung, orang tua mereka, dan masyarakat, rata-rata jawaban dari mereka menyebutkan bahwa orang tua tidak melarang anak-anaknya untuk menjadi pekerja ojek payung, dengan kata lain mereka membiarkan anak-anaknya menjadi pekerja ojek payung. Seperti halnya yang diungkapkan oleh bapak Ags:

"ya karna anak dibiarkan jadi otomatis ya dukungan itu tersirat tapi untuk mereka melarang itu ndak pernah ada. Dasare seneng, anaknya seneng orang tuanya ndukung yaudah piye akhire anak nggolek duit".

Walaupun dorongan dari

orang tua hanya tersirat dan tidak bersifat langsung, tetapi hal tersebut membuktikan bahwa para orang tua dari anak pekerja ojek payung tersebut tidak melarang anakanaknya untuk tidak bekerja. Justru mereka ikut senang karena anakanaknya memperoleh penghasilan banyak dan mereka juga mendapatkan sebagian dari penghasilan tersebut karena anakanak pekerja ojek payung akan memberikan sebagian dari penghasilan mereka untuk orang tuanya.
Dorongan yang sangat terlihat jelas dari para orang tua yaitu ketika mereka membelikan payung pada anaknya untuk ojek payung. Berdasarkan wawancara dengan Rng, Rng mengaku pertama kali mendapatkan payung karena dibelikan oleh orang tuanya. Begitu pula penuturan dari ibu SM, beliau mengatakan bahwa sebagian besar anak-anak yang menjadi pekerja ojek payung, payungnya dibelikan oleh orang tua mereka.

Selain orang tua, keluarga yang lain seperti saudara, kakek, nenek, dan saudara yang lain juga tidak pernah melarang anak-anak untuk tidak bekerja. Mereka semua membiarkan anak-anak bekerja di tengah derasnya hujan dan dingin yang bisa membahayakan kondisi kesehatan anak tersebut. Bapak Ags yang merupakan penduduk asli Kampung Pajeksan dan yang merupakan tetangga dari para pekerja ojek payung tersebut menyatakan bahwa:

"ya karna anak
dibiarkan jadi otomatis ya
dukungan itu tersirat tapi
untuk mereka melarang itu
ndak pernah ada, kakek,
nenek, apa saudara yang lain
gitu mbak yang tinggal
serumah juga ndak pernah
melarang".
Para keluarga akan ikut
karena sebagian dari


penghasilan yang diperoleh oleh anak-anak tersebut akan kembali lagi pada mereka, maksudnya penghasilan anak-anak pekerja ojek payung tersebut akan digunakan untuk mencukupi kebutuhan seharihari misalnya diberikan pada orang tua untuk membeli makan keluarga. Dari 9 anak pekerja ojek payung yang diwawancarai, sebagian dari penghasilan mereka diberikan untuk orang tuanya. Masyarakat kampung Pajeksan juga mengetahui bahwa anak pekerja ojek payung pasti akan memberikan sebagian penghasilannya untuk orang tua mereka. Salah satunya yaitu ibu Wwt: "ada sebagian yang uangnya diberikan orang tua ya ada, ada yang semuanya uangnya diberikan sama orang tua ya ada juga yang seperti itu".

Selain ibu Wwt, ibu SM juga menuturkan:

"ya ada sebagian, si itu Iho Atn itu uangnya buat ibunya, harus dikasihkan sama ibunya, ada juga mbak sebagian besar yang payungnya itu juga dibeliin orang tuanya".

Padahal anak-anak dibawah umur memiliki hak-hak tersendiri, dan mereka tidak layak untuk bekerja. Akan tetapi, para orang tua kurang memahami dan kurang mengerti akan hak-hak anak. Orang tua dari pekerja ojek payung ini rata-rata bekerja sebagai pedagang dan buruh dan kondisi ekonomi mereka lemah sehingga mereka sibuk bekerja mencari uang untuk mencukupi kebutuhan sehari-hari keluargnya. Mereka kurang dapat mengurus anak-anaknya karena mereka sibuk dengan urusan masing-masing dan para orang tua anak-anak tersebut juga lebih mementingkan bagaimana caranya mendapatkan uang untuk hidup daripada mengurus anaknya. Anak-anak akan dibiarkan begitu saja melakukan sesuatu tanpa adanya pengawasan dari orang tua, sehingga banyak orang tua yang kurang memberikan perhatian dan kasih sayang pada anak-anaknya. Anak dibiarkan bekerja, kehujanan dan kedinginan. Ibu SM menuturkan bahwa: "kebanyakan mereka anakanak yang orang tuanya bekerja, jadi ya orang tuanya sudah sibuk sendiri".

c. Kondisi Ekonomi

Pada umumnya, anak-anak mau menjadi pekerja ojek payung dikarenakan kebutuhan mereka dalam keluarga kurang tercukupi. Seperti yang diungkapkan oleh ibu SM: "ya itu kan karena ya terpaksa keadaan ekonomi". Karena anakanak sendiri, terus butuh uang buat jajan". Kurang tercukupinya kebutuhan anak dalam sebuah keluarga, memunculkan dorongan 
dalam diri anak tersebut untuk mbak, kalo kamu pengen makan memuaskan kebutuhan dirinya sendiri. Kebutuhan yang dimaksudkan di sini yaitu kebutuhan anak untuk jajan, untuk membeli buku ataupun sepatu.

Berdasarkan informasi dari informan, hasil dari menjadi pekerja ojek payung mereka gunakan untuk jajan, membeli sepatu, membeli buku, membeli susu dan untuk membayar uang sekolah, ada juga yang untuk ditabung, diberikan orang tua dan untuk makan keluarga. Seperti yang dikatakan oleh Rzk: "separoh buat dikasih orang tua separohnya lagi buat aku. Sama aku buat beli susu, buat jajan, kadang ya ditabung di sekolah kak". Hal ini diperkuat dengan pernyataan dari ibu SM: "mendukung karena ada juga yang uangnya nanti diberikan ke orang tuanya". Atn mengaku penghasilan yang ia dapat dari menjadi pekerja ojek payung yaitu untuk makan keluarga.

Faktor ekonomi keluarga, terutama keluarga dengan ekonomi yang rendah turut berperan dalam alasan anak bekerja. Ekonomi keluarga yang rendah, juga akan berpengaruh terhadap pola asuh anak. Seperti yang diungkapkan oleh ibu Ern: "kalo kamu pengen makan kerja, itu prinsip pokoknya saya keras

bekerja ". Pernyataan tersebut merupakan ajaran ibu Ern terhadap anaknya yaitu Atn. Walaupun anaknya masih dibawah umur, tetapi prinsip itu tetap diterapkan terhadap anaknya. Kondisi ekonomi keluarga yang lemah akan membuat anak bekerja lebih dini, yang pada akhirnya anak-anak akan lebih mementingkan mencari uang daripada pendidikan, bermain, atau yang lainnya.

Pada keluarga dengan kondisi ekonomi yang lemah, keputusan untuk bekerja sebagian besar datang dari anak sendiri, tetapi sebagian lain karena keinginan orang tua. Akan tetapi, dalam situasi krisis yang terjadi sekarang ini, kecenderungan keinginan orang tua untuk mempekerjakan anak menjadi semakin kuat karena penghasilan yang diperoleh orang tua tidak lagi mampu mencukupi kebutuhan hidup keluarga. Rendahnya pendapatan orang tua akan membuat mereka sulit memenuhi kebutuhan hidupnya yang pada akhirnya anak-anak tergerak untuk bekerja mencari uang demi mencukupi kebutuhan hidupnya yang tidak terpenuhi oleh orang tuanya dan semata-mata mereka bekerja demi untuk membantu orang tua mereka. 
Hal ini sangat memprihatinkan, karena kemiskinan akibat rendahnya tingkat penghasilan orang tua, imbasnya akan menimpa pada anak-anak. Anak-anak yang berasal dari keluarga dengan ekonomi yang lemah akan kurang terfasilitasi misalnya untuk membeli kebutuhan sekolah seperti tas, sepatu, dan buku, untuk sekedar jajan juga kadang tidak ada. Maka dari itu, anak-anak tertarik untuk terjun menggeluti pekerjaan ojek payung. Jika ikut bekerja menjadi pekerja ojek payung, anak-anak tersebut akan bisa memuaskan kebutuhannya yang tidak bisa tercukupi oleh keluarganya misalnya membeli sepatu, buku dan untuk jajan. Penghasilan yang mereka peroleh selain digunakan untuk memuaskan kebutuhannya sendiri, juga untuk membantu mencukupi kebutuhan keluarga seperti untuk makan.

Tidak dapat dipungkiri bahwa faktor-faktor di atas merupakan alasan utama seorang anak bekerja. Akan tetapi, terdapat faktor lain yang turut mendorong meningkatnya jumlah anak yang bekerja khususnya menjadi pekerja ojek payung, antara lain kebiasaan masyarakat setempat yang melatih anak bekerja sejak dini, minimnya pengetahuan, kesadaran, dan kepedulian tentang hak-hak anak oleh orang tua dan masyarakat sehingga keberadaan pekerja anak sudah merupakan sesuatu yang lumrah. Secara ideal fungsi keluarga sebagai fungsi ekonomi yakni dalam keluarga harus mampu mencukupi kebutuhan hidup setiap anggota keluarganya sesuai kemampuan setiap keluarga. Melihat hal tersebut keluarga anak yang menjadi ojek payung belum menjalankan fungsi ekonomi keluarga secara baik dengan membiarkan bahkan mendorong anak-anaknya untuk bekerja. Perubahan dalam struktural keluarga inti dengan fungsi sebenarnya keluarga terlihat dalam keluarga anak yang bekerja sebagai tukang ojek payung.

\section{Perubahan yang Terjadi dalam Struktur Keluarga Broken- Home}

Keluarga merupakan unit terkecil dari masyarakat, yang terdiri dari ayah, ibu, dan anak. Kesemua anggota keluarga tersebut mempunyai peranan, hak dan kewajiban, serta menjalankan fungsi keluarga yang berbeda-beda, namun pada hakikatnya akan saling melengkapi satu sama lain. Adapun untuk fungsi di dalam keluarga berupa fungsi biologis, fungsi ekonomi, fungsi pendidikan, fungsi 
sosialisasi, fungsi perlindungan, fungsi rekreasi, dan fungsi agama. Apabila dalam keluarga yang kondisinya masih utuh dalam arti tidak mengalami perpecahan (broken-home) maka tidak menutup kemungkinan semua fungsi tersebut bisa dijalankan dengan baik. Akan tetapi untuk keluarga yang mengalami perpecahan (brokenhome) maka ada beberapa fungsi yang hilang atau tidak bisa dijalankan dengan sepenuhnya.

Berdasarkan informasi yang diperoleh dari informan penelitian, beberapa faktor yang melatarbelakangi sebuah keluarga mengalami kondisi broken-home diantaranya sebagai berikut:

a. Hilangnya Rasa Kepercayaan Kepercayaan merupakan sebuah dasar dalam menjalin hubungan dengan pihak lain. Kepercayaan akan menjadi kekuatan untuk bisa merekatkan dan melanggengkan sebuah hubungan. Adanya kepercayaan bisa tumbuh karena adanya proses interaksi yang terjalin di antara kedua belah pihak. Interaksi tersebut akan menghasilkan dua bentuk yaitu asosiatif yang mengarah ke kerjasama maupun disosiatif yang mengarah ke perpecahan. Apabila di dalam sebuah keluarga sudah tidak ada lagi kepercayaan maka kekuatan hubungan mereka akan semakin melemah sehingga interaksi yang terbangun pun cenderung mengarah ke disosiatif. Sebagai dampaknya maka akan berujung perpecahan di dalam keluarga atau terjadinya broken-home.

Hal tersebut diungkapkan oleh salah satu informan yaitu bapak $\mathrm{MH}$ yang mengungkapkan: "tidak ada kepercayaan lagi dari istri terhadap saya." Hilangnya kepercayaan dari istri yang dialami oleh bapak $\mathrm{MH}$ dikarenakan faktor hubungan jarak jauh, sehingga istri mudah sekali untuk memikirkan hal-hal negatif yang belum tentu benar. Kepercayaan istri sedikit demi sedikit mulai hilang. Adanya hubungan jarak jauh sebenarnya tidak sangat berpengaruh untuk bisa melemahkan rasa kepercayaan, dengan syarat antara istri dan suami selalu menjaga komunikasi yang baik dan saling terbuka satu dengan yang lainnya maka kepercayaan akan tetap terjaga dengan baik.

b. Perbedaan Cara Pandang atau Prinsip

Dalam hidup, perbedaan cara pandang atau prinsip memang sangat wajar. Akan tetapi, di dalam keluarga apabila terjadi ketidakselarasan antara visi dan misi 
yang dibangun oleh pasangan maka akan menjadi penghambat keluarga tersebut untuk tetap utuh. Apalagi bagi pasangan yang menikah di usia dini maka cara berfikirnya masih mengutamakan emosi sehingga susah untuk dilebur untuk dijadikan satu prinsip hidup keluarganya. Masalah perbedaan cara pandang atau prinsip hidup juga diungkapkan oleh ibu MA yang mengungkapkan "saya dan suami saya berbeda prinsip hidup jadi sering sekali saya dan suami saya bertengkar.......".

Berbeda prinsip juga akan menimbulkan masalah baru yaitu dalam keluarga akan mudah terjadi perselisihan antara suami dan istri. Hal ini apabila dibiarkan terus menerus maka akan membuat ketidaknyamanan hidup bersama pasangan yang nantinya brokenhome adalah jalan yang dipilih.

c. Suami Tidak Memiliki Rasa Tanggung Jawab terhadap Istri dan Anak

Seorang suami mempunyai tanggung jawab yang besar bagi keluarga kecilnya. Suami harus memenuhi segala kebutuhan baik kebutuhan material maupun kebutuhan non material, karena peran suami adalah sebagai kepala rumah tangga. Jadi, segala bentuk kebutuhan apapun suami berkewajiban untuk memenuhinya. Adakalanya di dalam sebuah keluarga juga ditemukan seorang suami yang tidak bertanggung jawab dengan segala bentuk kebutuhan yang dibutuhkan oleh keluarganya. Hal tersebut jelas akan memicu terjadinya konflik di dalam keluarga. Apabila istri merasa tidak nyaman dengan kondisi demikian maka pada umumnya akan terjadi broken home. Hal tersebut juga diungkapkan oleh ibu SR yang mengungkapkan: "mungkin broken home adalah jalan yang terbaik, karena suami saya suka keluar malam dan tidak tanggung jawab sama istri mbak."

d. Faktor ekonomi

Faktor ekonomi adalah masalah yang paling krusial di dalam keluarga. Apabila kondisi keluarga ekonominya tercukupi maka segala macam kebutuhan hidup dapat terpenuhi dengan baik. Akan tetapi, apabila kondisi ekonomi di dalam keluarga kurang memadai maka kehidupan keluarga akan muncul permasalahan-permasalahan baru yang dapat berujung terjadinya konflik. Konflik yang muncul apabila mereka tidak mampu untuk mengatasinya maka akan memilih untuk broken home. Hal tersebut senada dengan ibu MA yang mengungkapkan “........., karena 
kurangnya ekonomi juga mbak jadi broken home adalah solusi yang terbaik."

Dari ungkapan salah satu informan tersebut dapat ditarik kesimpulan bahwa faktor ekonomi juga akan menentukan keharmonisan keluarga. Apabila sesama anggota keluarga mau untuk mensyukuri dan seorang suami tetap bertanggung jawab untuk memenuhi semua kebutuhan keluarga, maka konflik yang mengarah ke masalah ekonomi dapat terhindari. Akan tetapi apabila seorang suami tidak mau untuk memenuhi kebutuhan material maka akan rawan munculnya permasalahan-permasalahan yang bisa berdampak pada terjadinya broken home.

Berdasarkan dua contoh kasus di atas, struktur dan fungsi di dalam masyarakat sudah banyak berubah. Sejalan dengan itu, keluarga dan unit rumah tangga pun telah mengalami banyak perubahan dan penyesuaian. Ada berbagai faktor penyebab yang melahirkan perubahan dalam struktur keluarga di masyarakat, baik yang bersifat internal maupun eksternal.

Keluarga didefinisikan sebagai kelompok yang diikat oleh kekerabatan, tempat tinggal, atau ikatan emosional yang dekat, dan mereka menunjukkan empat gambaran sistemik; ketergantungan antar anggotanya, pemeliharaan lingkungan selektif sekitarnya, kemampuan beradaptasi terhadap perubahan dan memelihara identitas mereka sepanjang waktu, keragaan tugas-tugas keluarga (Megawangi, 2001). Tugas-tugas keluarga diantaranya adalah: pemeliharaan fisik, sosialisasi dan pendidikan, kontrol sosial dan perilaku seksual, pemeliharaan moral keluarga dan motivasi untuk berperan di dalam dan di luar keluarga, akuisisi anggota keluarga baru baik melalui prokreasi ataupun adopsi, dan melepas anggota keluarga muda ketika sudah dewasa.

Dalam kaitannya dengan penelitian ini, anak sebagai aktor utama yang menjadi fokus pembahasan telah mengalami berbagai perubahan terkait status yang disandangnya di dalam keluarga. Anak yang bekerja sebagai tukang ojek payung misalnya, meskipun hanya bekerja pada musim hujan saja, namun uang yang diperolehnya digunakan untuk membantu memenuhi kebutuhan keluarga sehari-hari. Penghasilan yang diperoleh selain untuk memenuhi kebutuhan sekolah (membeli sepatu, buku, seragam) 
juga ada yang diserahkan kepada orang tuanya. Orang tua mereka pun senang mendapatkan uang dari anak-anak mereka yang belum genap berusia 15 tahun tersebut.

Contoh lainnya adalah anakanak yang berasal dari keluarga broken-home. Mereka memang tidak bekerja seperti anak-anak pada contoh sebelumnya. Namun, jika melihat gambaran fungsi keluarga yang ada di dalam keluarga broken home, maka tidak bisa berjalan optimal. Bila dianalisis dengan menggunakan teori struktural fungsional, terlihat bahwa dalam keluarga yang mengalami broken home, orang tua kurang maksimal dalam menjalankan fungsi keluarga dengan baik. Fungsi keluarga yang kurang terpenuhi adalah masalah ekonomi dan kasih sayang, sedangkan untuk masalah fungsi keluarga yang lain bisa dilihat tergantung bagaimana pola asuh yang diterapkan oleh masing-masing keluarga. Namun, apabila keluarga yang masih utuh dalam artian tidak mengalami broken home, maka semua fungsi-fungsi keluarga akan terpenuhi dengan baik terhadap anak.

Fungsi keluarga sangat bervariasi tergantung darimana titik pandang kita melihat, jenis keluarga (inti atau luas), demikian juga sistem sosial dimana keluarga tinggal. Namun demikian fungsi dasar keluarga paling tidak mencakup: (1) penguatan ikatan ekonomi, sosial, dan emosional diantara pasangan suami-istri, (2) hubungan seksual dan prokreasi diantara pasangan, (3) pemberian nama dan status, khususnya kepada anak, (4) perawatan dan perhatian kepada anak, (5) sosialisasi dan pendidikan anak, (6) perlindungan anggota keluarga, (7) rekreasi dan perhatian emosional anggota keluarga, dan (8) pertukaran barang dan jasa.

Arah perkembangan keluarga sangat berkaitan dengan perubahan sistem sosialnya. Perubahan kehidupan keluarga dari tradisional/pra modern menjadi modern dan post modern dapat dilihat dari aspek jenis keluarga, landasan dan kondisi hubungan suami istri, serta praktek pembesaran anak. Pada sistem sosial tradisional/pre modern, dimana masih dominannya pertanian dan budaya pertanian, umumnya adalah bentuk keluarga luas (extended) dan hubungan kekerabatan masih erat. Keluarga besar ikut serta berbagi peran dalam praktek pembesaran anak. Keluarga tradisional menekankan pentingnya harmoni 
dengan lingkungan. Segala persepsi pemikiran, dan perasaan tercermin secara detail dalam simbol-simbol, ritual, dan adat-adat di lingkungannya.

Keluarga inti modern dibentuk oleh tiga sentimen (Zeitlin et al, 1995); pasangan romantic love, dimana pernikahan dilakukan bukan karena alasan kekayaan dan status sosial, persepsi bahwa wanita memiliki naluri keibuan dan peduli terhadap anak, serta kepercayaan bahwa hubungan individu dalam keluarga lebih erat dibandingkan hubungan di luar keluarga. Pada keluarga modern terjadi perubahan antara nilai sosial, struktur keluarga, teknologi, dan struktur masyarakat. Hubungan suami istri lebih menunjukkan kesetaraan, akibat dari meningkatnya posisi tawar (bargaining position) wanita.

\section{Banyak tekanan-tekanan} eksternal terhadap keluarga, serta terdapatnya perbenturan pelaksanaan fungsi-fungsi keluarga dapat menyebabkan kondisi chaos dan kejenuhan sosial dalam kehidupan keluarga. Dominannya budaya materill dan meningkatnya pendidikan dan keterampilan wanita membuat keluarga senantiasa dihadapkan pada dua pilihan: meningkatkan pendapatan dengan masuknya wanita ke sektor publik atau melaksanakan fungsi pembesaran dan pengasuhan anak. Persaingan kerja yang semakin kompetitif, stress pekerjaan, kesulitan membagi waktu, rasa bersalah karena mengabaikan peran pengasuhan merupakan situasi dan kondisi yang sering ditemui keluarga yang istrinya bekerja. Kondisi tersebut dapat mengakibatkan ketidakberlangsungan keluarga sebagai akibat kejenuhan sosial dalam kehidupan keluarga dan dapat mengakibatkan apa yang disebut sebagai keluarga mengambang (floating family).

Keluarga postmodern dicirikan dari pengakuan berbagai nilai dan kepercayaan yang beragam yang membawa ke situasi toleransi yang lebih besar terhadap perbedaan-perbedaan pandangan hidup. Sisi negatif dari pemahaman tersebut adalah terdapatnya kebebasan, kesejahteraan yang lebih baik dan kesempatan yang lebih besar untuk eksplorasi kehidupan.

Berdasarkan contoh kasus yang diangkat dalam penelitian ini, terlihat bahwa keluarga yang hakikatnya sebagai lembaga pertama dan utama berlangsungnya tumbuh kembang anak, dewasa ini juga tidak terlepas dari terpaan gelombang 
transformasi sosial. Konsep keluarga yang semula merupakan kesatuan sosial terkecil, yang terdiri ayah, ibu dan anak yang terbentuk melalui perkawinan, telah mengalami perubahan. Unsur ayah, ibu, anak dan perkawinan tidak selalu terpenuhi dalam konsep keluarga dewasa ini. Berubahnya struktur keluarga ini, tentu akan mempengaruhi peran dan fungsi keluarga. Dalam kedua contoh kasus yang diajukan, anak tidak lagi berada dalam posisi nyaman dan aman di keluarga. Baik itu anak-anak yang bekerja sebagai tukang ojek payung, maupun anak-anak yang berasal dari keluarga broken-home.

\section{Simpulan}

Perubahan sosial dewasa ini telah menimbulkan efek yang tidak diinginkan terhadap eksistensi dan ketahanan keluarga. Peran dan fungsi sebagian keluarga tidak dapat dilaksanakan dan bahkan sudah mengarah pada disorganisasi sosial keluarga. Komunikasi, interaksi dan relasi sosial antar anggota keluarga batih (keluarga inti) maupun dengan keluarga luas kurang kondusif, dan bahkan berpotensi melahirkan konflik. Pada beberapa kasus, hubungan antar orangtua (suami istri atau ayah - ibu) mengalami permasalahan, baik itu terkait ekonomi keluarga, pemenuhan kebutuhan hidup; sehingga anak menjadi korban. Dalam penelitian ini, anak yang bekerja sebagai tukang ojek payung ternyata ikut andil dalam membantu perekonomian keluarga meskipun mereka hanya bekerja pada musim hujan saja. Di sisi lain, anak-anak yang berasal dari keluarga broken-home juga tidak dapat tumbuh dan berkembang secara optimal karena terjadi disfungsi dalam keluarga. Artinya, mereka sebagai anak tidak mendapatkan fungsi afeksi, sosialisasi, maupun proteksi dari orang tua.

\section{Ucapan Terima Kasih}

Terimakasih disampaikan kepada semua pihak yang terlibat dalam penelitian ini sehingga terlaksana dengan baik dan tim redaksi Jurnal Pendidikan Sosiologi Fakultas IImu Sosial UNY yang telah mempublikasikan penelitian ini.

\section{Daftar Pustaka}

Abdulsyani. 2007. Sosiologi; Skematika Teori, dan Terapan. Jakarta: Bumi Aksara.

Khairuddin. 2002. Sosiologi Keluarga. Yogyakarta: Liberty. Megawangi, R. 2001. Membiarkan Berbeda: Sudut Pandang Baru tentang Relasi Gender. Bandung: Mizan 
Puspitawati, H. 2012. Gender dan Keluarga: Konsep dan Realita di Indonesia. Bogor: IPB Press. . 2009. Teori

Struktural Fungsional dan Aplikasinya dalam Kehidupan Keluarga. Bogor: Departemen IImu Keluarga dan Konsumen, Fakultas Ekologi Manusia IPB. 2006. Pengaruh

Faktor Keluarga, Lingkungan Teman dan Sekolah Terhadap Kenakalan Pelajar di Sekolah Lanjutan Tingkat Atas (SLTA) di Kota Bogor. Disertasi. Bogor : Sekolah Pascasarjana IPB.

Septiarti, S. Wisni. 2002. Fenomena Pekerja Anak Usia Sekolah. Jurnal Penelitian Humaniora. Vol. 7, No. 1, April 2002: 27-46.

Soekanto, Soerjono. 2004. Sosiologi Keluarga. Tentang Ikhwal Keluarga Remaja dan Anak. Jakarta: Rineka Cipta. 